5. Steib C. Treatment with the leukotriene inhibitor montelukast for 10 days attenuates portal hypertension in rat liver cirrhosis / C. Steib, M. Bilzer, M. Winkel et al. // Hepatology. - 2010. - Vol. 51, № 6. - P. 86-96.

6. Rajeshwar P. The puzzle of endothelial nitric oxide synthase dysfunction in portal hypertension / P. Rajeshwar, V. Balasubramaniyan, R. Jalan // Hepatology. - 2007. - Vol. 46, №3. - P. 943-946.

7. Rodrigues-Vilarrupa A. Current concepts on the pathophysiology of portal hypertension / A. RodriguesVilarrupa, M. Fernandez, J. Bosh // Annals of Hepatology. - 2007. - Vol. 6, № 1. - P. 28-36.

Виноградова Е., Янчук Петр, Пасичниченко Олег. Роль лейкотриенов в реализации тонической сократительной активности воротной вены под влиянием ацетилхолина в условиях нормы и экспериментальной портальной гипертензии. Исследовали участие лейкотриенов в механизме опосредования действия ацетилхолина на сократительную тоническую активность изолированых препаратов воротной вены крыс. Блокатор фермента 5-липоксигеназы зилеутон $\left(4,2 \cdot 10^{-5}\right.$ моль/л) угнетал сократительную активность воротной вены, индуцированную ацетилхолином $\left(2 \cdot 10^{-5}\right.$ моль/л), на $23 \%$ относительно контрольних значений. У крыс с натрий-йодной моделью портальной гипертензии лейкотриены также задействованы в реализации действия ацетилхолина. Зилеутон угнетал вызванные ацетилхолином реакции таких сосудов на 11 \% относительно контроля. Полученные нами результаты свидетельствуют об участии продуктов липоксигеназного пути превращения арахидоновой кислоты в реализации сократительной тонической активности воротной вены, индуцированой ацетилхолином, у крыс как в условиях нормы, так и при экспериментальной портальной гипертензии.

Ключевые слова: воротная вена, ацетилхолин, лейкотриены.

Vynogradova O., Yanchuk Petro, Pasichnichenko Oleg. Role of Leukotrienes in Release of Contractile Reactions of Portal Vein, Induced by Acetylchline. Effects of zileuton $\left(4,2 \cdot 10^{-5} \mathrm{~mol} / \mathrm{L}\right)$ on tonic contractile activity of the rat portal vein preparations, induced by acetylcholine $\left(2 \cdot 10^{-5} \mathrm{~mol} / \mathrm{L}\right)$ were investigated. Partial inhibition of the contractions by lipoxigenase blocker zileuton on $23 \%$ suggests, that products of lipoxigenase pathways of arachidonic acid conversion are involved in mechanisms of specified reactions. Zileuton depress tonic contraction of isolated segments of vessels with $\mathrm{NaJ}$-model of portal hypertension on $11 \%$, indicating a paticipation of leukotrienes in this reaction.

Key words: acetylcholine, portal vein, thromboxane, leukotrienes.

Стаття надійшла до редколегії 23.01.2015 p.

УДК $612.897 \pm 06: 612.172$

Олена Волошин

Ірина Чень

Володимир Волошин

\title{
Характер психомоторних реакцій в осіб із різним рівнем фізичної працездатності
}

Досліджували зорово-моторну реакцію, оцінку часових інтервалів і коректурну пробу задля вивчення специфіки психофізіологічних реакцій організму осіб з різним рівнем фізичної працездатності. За винятком швидкості зорово-моторної реакції, всі досліджувані показники мають якісно вищий рівень в осіб із середнім і високим рівнями індексу Руф'є та нормальною частотою серцевих скорочень.

Ключові слова: психофізіологічний стан, рівень фізичної працездатності, зорово-моторна реакція, коректурна проба, оцінка часових інтервалів.

Постановка наукової проблеми та її значення. Одним із найвагоміших чинників ефективності адаптації індивідуума в середовищі є специфіка його психофізіологічного статусу, рівень адекватності реакцій нервової системи. Успішність останніх визначається індивідуальними особливостями роботи нервової системи, які, в свою чергу, залежать від генетично успадкованих можливостей. Автори досліджень у цьому напрямі зазначають, що актуальність пошуку об'єктивних показників

(C) Волошин О., Чень I., Волошин В., 2015 
психомоторних якостей людини не викликає сумнівів, оскільки вони $є$ обов'язковими критеріями валідної діагностики психофізіологічного статусу [2]. Водночас, вагоме значення в цьому процесі мають й умови середовища. Зокрема, незважаючи на те, що широкий діапазон адаптаційних можливостей людини дає змогу пристосовуватися до будь-якої погоди, несприятливі погодні умови викликають зростання латентних періодів зорово-моторних реакцій, водночас збільшуючи кількість помилкових реакцій [6].

Дослідження особливостей психо-емоційного та функціонального стану організму загалом і в осіб з різним рівнем фізичної працездатності зокрема - це один з актуальних напрямів у сучасній фізіології. Серйозним індикатором рівня фізичної працездатності і функціонального стану організму в цілому є ефективність серцевої діяльності. Частоту серцевих скорочень успішно використовують як критерій напруженості адаптаційних процесів організму, успішності його психомоторних реакцій включно. Вагомим фактором, що сприяє цьому, є інтенсивний розвиток сучасних цифрових технологій. Використання комп'ютерного програмного забезпечення суттєвим чином оптимізує дослідження у цій сфері, зводить до мінімуму особистісний вплив експериментатора на психоемоційний стан обстежуваного і підвищує рівень об'єктивності результатів.

У дослідженнях, присвячених цій проблематиці, автори відзначають, що важливе завдання вивчення впливу психічних суб'єктивних станів на комплекс об'єктивних психофізіологічних і фізіологічних показників, оскільки на фізіологічний стан людини великий вплив має його психоемоційний стан [9]. Експериментальні й теоретичні роботи у цій сфері фізіології безпосередньо пов'язані 3 практикою, зокрема в педагогічній галузі. Так, дослідники вказують, що навчання у сучасних умовах пов'язане 3 потребою засвоєння великого обсягу інформації, що може спричинити напруження фізіологічних систем і психіки учнів. Проте врахування індивідуально-особистісних особливостей студентів може сприяти підвищенню якості навчання і забезпечити успішність їхньої майбутньої професійної діяльності [7].

Існує також певна вікова специфіка у перебігу процесів вищої нервової діяльності. Так, при дослідженні особливостей сприйняття коротких проміжків часу старшими школярами залежно від типу моторної асиметрії встановлено, що незалежно від моторної асиметрії досліджуваних, усі запропоновані проміжки часу переоцінювались, тобто мали чітку тенденцію до прискорення [4]. Про безпосередній вплив особливостей сенсо-моторних реакцій на якість навчання свідчать кореляційні взаємозв'язки між показниками, що характеризували прояв здібностей до відтворення, оцінки та диференціації просторових, часових і силових параметрів рухів та якістю оволодіння учнями технічними елементами спортивних ігор [1].

Слід відзначити і вплив на психофізіологічний стан людини тривалості та інтенсивності розумового навантаження, що, за певних умов, може призвести до змін у характері реактивності нервової системи і якості адаптивних реакцій в цілому. У роботах, присвячених цьому питанню, зазначено, що увага є однією з найважливіших психофізіологічних функцій, які забезпечують оптимізацію процесів виховання і навчання [3]. Водночас дослідження показали, що з позицій фізіології інтелектуальна діяльність відрізняється великим мозковим напруженням, зумовленим концентрацією уваги на обмеженому колі явищ або об'єктів. Автори дослідження зазначають, що внаслідок цього процес збудження у центральній нервовій системі зосереджений у порівняно невеликій ділянці нервових центрів, що зумовлює їх швидку втомлюваність [8].

Окрім аналізу характеру і динаміки психомоторних реакцій, важливим напрямом сучасної психофізіології є дослідження особливостей оцінки людиною часових проміжків. Специфіка такої оцінки впливатиме на загальний результат у процесі реалізації поведінкової реакції індивідуума. Зокрема, дослідники зазначають, що вивчення часових властивостей людини представляє надзвичайно важливе завдання і на психічному, і на фізіологічному рівнях [5]. Слід враховувати, що психофізіологічний стан суттєво залежить від ефективності роботи серцево-судинної системи, яка є одним із визначальних факторів працездатності організму в цілому і нервової системи зокрема.

3 огляду на зазначене вище, мета нашої роботи - вивчити особливості зорово-моторної реакції, оцінки часових інтервалів і показників коректурної проби в осіб з різним рівнем фізичної працездатності.

Об'єкт і методи дослідження. В ході роботи було обстежено 60 осіб віком 20-22 роки. В обстежених вивчали швидкість зорово-моторної реакції (простої і диференційованої), оцінку часових інтервалів і показники коректурної проби. У дослідженні використана комплексна діагностична комп'ютерна програма «Фізіолог». 
Дослідження швидкості зорово-моторної реакції передбачало оцінку середнього часу простої і диференційованої зорово-моторної реакції, а також кількість помилок, допущених при обстеженні. Вивчення особливостей оцінки часових інтервалів допомагає визначити, наскільки об'єктивно учасники дослідження сприймають часові інтервали. Аналіз показників коректурної проби дає змогу встановити кількість підрахованих літер і різницю цього показника із загальною кількістю літер у тексті, час виконання тесту, а також темп виконання і показник переключення уваги.

Для розподілу контингенту обстежуваних на групи за рівнем фізичної працездатностіi загального стану серцево-судинної системи учасникам дослідження вимірювали частоту серцевих скорочень (ЧСС), артеріальний тиск і визначали індекс проби Руф'є. Проба Руф'є - це простий непрямий метод визначення фізичної працездатності, у якому використовуються значення частоти серцевих скорочень у різні часові періоди відновлення після порівняно невеликих навантажень.

Виклад основного матеріалу та обтрунтування отриманих результатів дослідження. Серед контингенту обстежених домінували особи із середнім рівнем індексу Руф'є - 53\%, другу за чисельністю групу сформували особи із задовільним рівнем проби Руф' $€-27 \%$, на групи із високим і низьким рівнями індексу Руф’є припадає по 10 \% відповідно.

Дослідження артеріального тиску в обстежених з різним рівнем індексу Руф’є свідчить, що в усіх осіб він у межах фізіологічної норми, однак простежується певна тенденція: в осіб з низьким рівнем працездатності середнє значення артеріального тиску становило 121,66 $\pm 6,10$ і 78,33 $\pm 3,80$ мм рт. ст., тоді як в інших групах не перевищував $115,31 \pm 5,5$ і 75,00 $\pm 3,64$ мм рт. ст. Отже, серед обстежених переважають особи з середнім і задовільним рівнем фізичної працездатності.

Аналіз показників швидкості зорово-моторної реакції засвідчив, що найкоротший час простої реакції в осіб із задовільним і низьким рівнями фізичної працездатності, відповідно $0,33 \pm 0,01 \mathrm{c} \mathrm{i}$ $0,35 \pm 0,02$ с (рис. 1). Аналогічну ситуацію відзначено і при дослідженні диференційованої зоровомоторної реакції: $0,36 \pm 0,02$ с і $0,39 \pm 0,02$ с в обстежених з низьким і задовільним рівнем індексу Руф'є відповідно проти $0,44 \pm 0,05$ с і $0,45 \pm 0,06$ с - в осіб із середнім і високим рівнями фізичної працездатності. Вказані результати можна трактувати як свідчення ефективнішої обробки зорової сенсорної інформації нервовою системою осіб із задовільним індексом Руф'є порівняно з обстеженими із високим рівнем фізичної працездатності.

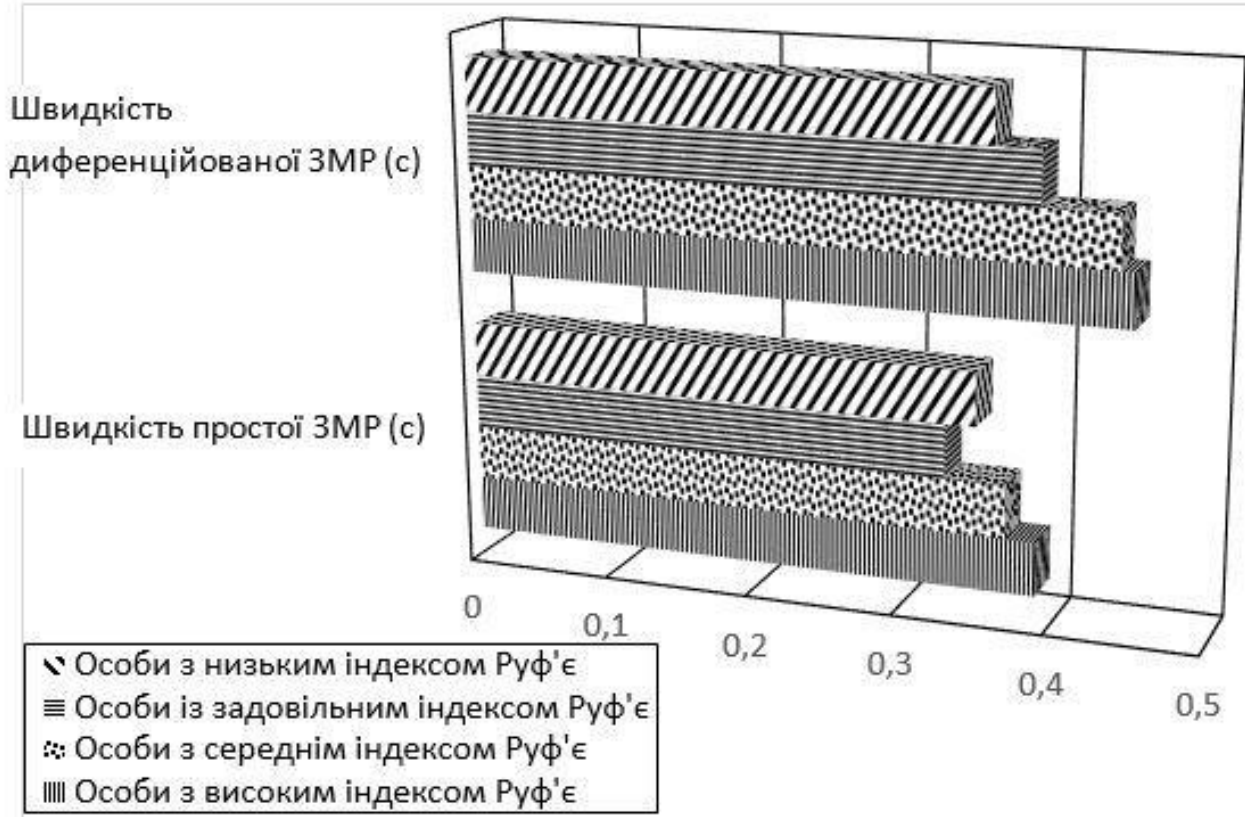

Pис. 1. Показники швидкості зорово-моторної реакції (ЗМР) в осіб із різним індексом Руф'є

Дослідження особливостей сприйняття часових інтервалів показало, що серед обстежених із високим і середнім рівнями фізичної працездатності кількість осіб, що реально оцінили часовий інтервал, становить 16,70 \% і 15,62 \% відповідно. У групі із задовільним рівнем індексу Руф'є цей 
показник становить $6,25 \%$, а серед осіб з низьким рівнем фізичної працездатності жоден з обстежених не продемонстрував реальної оцінки часового інтервалу.

Аналіз результатів коректурної проби серед осіб з різною ЧСС засвідчив, що в групі зі зниженою частотою серцевих скорочень найвище значення рівня концентрації уваги $-6897,51 \pm 307,16$, тоді як у середньому серед усього контингенту обстежених цей показник становить 4534,04 $\pm 194,25$ (табл. 1). Водночас в обстежених 3 нормальною і підвищеною ЧСС значення цього показника суттєво нижчі. Середне значення темпу виконання вказаного тесту серед усіх груп обстежених становило $0,688 \pm 0,03$. При цьому в групі осіб із зниженою ЧСС цей показник має значення $0,747 \pm 0,03$, з ЧСС у межах норми $-0,671 \pm 0,04$, а в осіб з підвищеною ЧСС $-0,647 \pm 0,02$. Отже, чим напруженіший ритм серцевої діяльності, тим менше значення темпу виконання цього завдання. 3 цими даними узгоджуються і результати аналізу часу виконання завдання: в середньому цей показник має значення $159,50 \pm 7,53 \mathrm{c}$, тоді як в осіб зі зниженою ЧСС він становить $148,80 \pm 6,82$ с, а в обстежених 3 підвищеною ЧСС $-166,58 \pm 8,01 \mathrm{c}$.

Показник переключення уваги має найвище значення в осіб зі зниженою ЧСС 92,6 $\pm 4,19 \%$, тоді як в обстежених 3 підвищеною частотою серцевих скорочень він становив 85,54 4,03 \%, а середнє значення серед усього контингенту обстежених відповідає 90,06 $\pm 4,23$ \% (табл. 1).

Таблиця 1

Показники швидкості зорово-моторної реакції (ЗМР) осіб з різною ЧСС

\begin{tabular}{|l|c|c|c|c|}
\hline $\begin{array}{l}\text { Група } \\
\text { обстежених }\end{array}$ & Час виконання, с & $\begin{array}{c}\text { Рівень } \\
\text { концентрації }\end{array}$ & Темп виконання & $\begin{array}{c}\text { Показник } \\
\text { переключення } \\
\text { уваги }\end{array}$ \\
\hline Знижена ЧСС & $148,80 \pm 6,82$ & $6897,51 \pm 307,16$ & $0,747 \pm 0,03$ & $92,6 \pm 4,19$ \\
\hline Нормальна ЧСС & $163,13 \pm 7,54$ & $4534,04 \pm 194,25$ & $0,671 \pm 0,04$ & $92,06 \pm 3,88$ \\
\hline Підвищена ЧСС & $166,58 \pm 8,01$ & $3211,45 \pm 141,94$ & $0,647 \pm 0,02$ & $85,54 \pm 4,03$ \\
\hline
\end{tabular}

Висновки та перспективи подальшого дослідження. Отже, за результатами аналізу зоровомоторної реакції найбільшушвидкість у виконанні завдання демонструють особи із задовільним рівнем фізичної працездатності. Водночас, ступінь реальності оцінки часових інтервалів ефективніший в обстежених із середнім і високим значеннями індексу Руф'є.

Напруженість серцевої діяльності як індикатор інтенсивності адаптаційних процесів помітно вплинула на ефективність показників коректурної проби. Так, найнижчі значення рівня концентрації, темпу виконання і показника переключення уваги відзначено в осіб з підвищеною ЧСС на фоні найбільшої витрати часу на виконання коректурної проби.

Вивчення характеру і динаміки психомоторних реакцій в осіб з різним рівнем фізичної працездатності є частиною комплексного дослідження задля підвищення об'єктивності оцінки психофізіологічного стану організму. Зокрема, аналіз особливостей зорово-моторної реакції, оцінки часових інтервалів і показників коректурної проби дає змогу отримати інформацію, що сприятиме оптимізації і корекції навчального процесу.

\section{Докерела та література}

1. Бойчук Р. І. Особливості прояву здібностей до оцінки просторово-часових і динамічних параметрів рухів у школярів в процесі навчання технічних елементів спортивних ігор [Електронний ресурс] / Р. I. Бойчук, С. А. Бублик // Вісн. Чернігів. нац. пед. ун-ту. Педагогічні науки : Фізичне виховання та спорт . - 2013. Вип. 112(1). - С. 59 - 62. - Режим доступу : http://nbuv.gov.ua/j-pdf/VchdpuPN_2013_112(1)__14.pdf.

2. Дегтяренко Т. В. Індивідуалізована оцінка психомоторних якостей за об'єктивними показниками зорової аферентації та їх взаємозв'язки з когнітивними функціями людини / Т. В. Дегтяренко, О. В. Ушан, О. С. Іванова // Фізіол. журн. - 2008. - Т. 56, № 2. - С. 62-63.

3. Запорожець О. П Дослідження показників уваги молодших школярів з різною спрямованістю спортивних тренувань / О. П. Запорожець // Фізіол. журн. - 2008. - Т. 56, № 2. - С. 64-65.

4. Коцан I. Я. Особливості сприйняття коротких проміжків часу старшими школярами залежно від типу моторної асиметрії [Електронний ресурс] / І. Я. Коцан, Т. В. Качинська, Ю. В. Збирун // Наук. вісн. Вол. нац. ун-ту ім. Лесі Українки. Біол. науки : Фізіологія людини і тварин. - 2012. - № 2. - С. 65 - $70 .-$ Режим доступу : http://esnuir.eenu.edu.ua/bitstream/123456789/ 1359/3/ kotsan.pdf

5. Микула М. М. Вплив метеорологічних факторів на зміни зорово-моторних реакцій у студентів 3 різним рівнем тривожності : Зб. наук. пр. V Всеукр. науко-практ. конф. молодих учених і студентів [Електрон- 
ний ресурс] / М. М. Микула, В. О. Киричук / Біол. дос. - 2014. - Житомир : Вид-во ЖДУ ім. І. Франка, 2014. - С. 357 - 359. - Режим доступу : http://eprints.zu.edu.ua/10964/1/M._М._Микула1_В._О._Киричук2.pdf.

6. Махін С.А. Відмірювання часових інтервалів: аналіз ЕЕГ і викликаних потенціалів мозку : автореф. дис. ... канд. біол. наук [Електронний ресурс] / С. А. Махін. - Тавр. нац. ун-т ім. В. І. Вернадського. - Сімферополь, 2003. - 16 c. - Режим доступу : http://librar.org.ua/ sections_load.php?s=biological_sciences\&id=232

7. Овсянникова Н. М. Структурний аналіз психофізіологічних характеристик студентів різної статі [Електронний ресурс] / Н. М. Овсянникова // Таврич. медико-биол. вест. - 2013. - Т. 16, №4 (64). C. 113 - 116. - Режим доступу : http://irbis-nbuv.gov.ua/cgi-bin/irbis_nbuv/ cgiirbis_64.exe?C21COM= $2 \& I 21 D B N=U J R N \& P 21 D B N=U J R N \& I M A G E \_F I L E \_D O W N L O A D=1 \& I m a g e$ file_name=PDF/Tmbv_2013 _16_4_28.pdf

8. Халфин Р. М. Особенности коррекции зрительной работоспособности офисных служащих мужчин 2935 лет [Электронный Ресурс] / Р. М. Халфин, П. А. Байгужин, Э. Ш. Шаяхметова, Р. В. Королев // Фундамент. исслед. -2013. - №10, Ч. 14. - Режим доступа : http://www.rae.ru/f s/?section=content\&op= show_article\&article_id=10002244

9. Хорсева Н. И. Методические подходы к обработке индивидуальных данных компьютеризированного мониторинга функционального состояния человека. Часть 1. Учет параметров психоэмоционального состояния [Электронный ресурс] / Н. И. Хорсева, П. Е. Григорьев // Таврич. медико-биол. вест. - 2010. T. 13, № 3 (51). - С. 242 - 246. - Режим доступа : http://dspace.nbuv.gov.ua/ bitstream/handle/123456789/ 25562/50-Khorseva.pdf

Волошин Елена, Чень Ирина, Волошин Владимир. Характер психомоторных реакций у людей разным уровнем физической работоспособности. Исследовали зрительно-моторную реакцию, оценку временных интервалов и корректурную пробу с целью изучить специфику психофизиологических реакций организма у людей с разным уровнем физической работоспособности.С целью распределения на группы по уровню работоспособности и общего состояния сердечно-сосудистой системы участникам исследования измеряли частоту сердечных сокращений, артериальное давление и определяли индекс пробы Руфье.

Степень реальности оценки временных интервалов наиболее высокий у обследованных со средним и высоким значениями индекса Руфье. Самые низкие значения уровня концентрации, темпа исполнения и показателя переключения внимания отмечены у лиц с повышенной частотой сердечных сокращений на фоне наибольших затрат времени на выполнение корректурной пробы. За исключением скорости зрительно-моторной реакции, качественный уровень всех исследованных показателей более высокий у лиц со средним и высоким индексами пробы Руфье и нормальной частотой сердечных сокращений.

Ключевые слова: психофизиологическое состояние, уровень физической работоспособности, зрительномоторная реакция, корректурная проба, оценка временных интервалов

Voloshyn Olena, Chen' Iryna, Voloshyn Volodymur. The Character of Psycho-motor Reactions in Individuals with Different Levels of Physical Performance. Experimental studies examined the visual-motor response and assessment of time intervals and proofreading test for the study of specific of psychophysiological responses of individuals with different levels of physical performance.

It was measured the heart rate (HR), blood pressure and determined the index of Rufye's test for the distribution of contingent of surveyed into groups according to their level of physical performance and general condition of their cardiovascular system.

It was revealed that individuals with moderate and high scores of Rufye's index characterized by the highest degree of reality of assessment of time intervals. Persons with increased heart rate have the lowest value of the level of concentration, tempo of execution and indicator of switching of attention. They are characterized by the value of time spending at proofreading test. All studied parameters (except for the speed of visual-motor response) have qualitatively higher level in individuals with medium and high levels of Ruf'ye index and normal heart rate.

Key words: psychophysiological state, level of physical performance, visual-motor reaction, proofreading test, estimation of time intervals.

Стаття надійшла до редколегії 26.01.2015 p. 